\title{
The analysis of small- and mesoscale dispersion patterns of Marenzelleria viridis (Polychaeta: Spionidae) in a coastal water area of the southern Baltic
}

\author{
M. L. Zettler \& A. Bick \\ Universität Rostock, WB Meeresbiologie und Allgemeine und Spezielle Zoologie; \\ D-18051 Rostock, Germany
}

\begin{abstract}
The horizontal mesoscale distribution of Marenzelleria viridis (Verrill, 1873), a spionid polychaete introduced from North American coastal waters during the 1980s, was studied in shallow water in the southern Baltic (German coast). The polychaete achieved an individual dominance of $80 \%$ and abundances up to around $8500 \mathrm{ind} . / \mathrm{m}^{2}$. Samples taken from a small $(1.2 \mathrm{~m} \times 1.2 \mathrm{~m}, 6 \times 6$ samples, depth $0-35 \mathrm{~cm})$ and a large station grid $(5.5 \mathrm{~m} \times 5.5 \mathrm{~m}, 11 \times 11$ samples, depth $0-35 \mathrm{~cm})$ were used to calculate dispersion indices for subpopulations of adult and juvenile $M$. viridis and subdominant chironimids (the Chironomus plumosus and Ch. halophilus complexes). The distribution patterns were significantly patchy. The patch sizes were estimated with the help of the dispersion indices and by analysing the correlograms in which spatial autocorrelations such as Moran's I and Geary's $c$ values were plotted versus the field distance $k$. The patch sizes were heterogenous. The smallest patches found were $0.04 \mathrm{~m}^{2}$. The largest sizes observed were $9 \mathrm{~m}^{2}$. It is conceivable that smaller patches merge to form larger aggregations. Calculation of the abundance and rank correlations between subpopulations revealed significant positive relationships. These indicate principal suspension feeding. Sediment structure, substrate preference, feeding mode and biotic or abiotic attraction centres are considered to be the main causes of aggregation and the positive correlations
\end{abstract}

\section{INTRODUCTION}

Population distributions reflect the dynamics and events of the life cycle, including birth, death and migration (Poole, 1974). They are influenced by both biotic and abiotic factors, among which only heterogeneity of the environment (e.g. water depth, sediment, exposure), interactions between individuals of one or more species (for instance competition, predation) and, naturally, anthropogenic influences (pollution) will be mentioned as examples (Pielou, 1977; Reise, 1991; Sastre, 1985).

Most analyses of the small-scale distribution of aquatic life forms analysed (e.g. de Alava \& Defoe, 1991; Eckman, 1979; Trueblood, 1991) have dealt with shallow-water areas, but some have been performed for deep sea regions (Jumars, 1975; Jumars \& Eckman, 1983) and the pelagic zone (McGurk, 1987). Distribution patterns can be patchy, random, or uniform (Pielou, 1969, 1977).

Most species, including mussels (Burla et al., 1974; Sastre, 1985), meiobenthic crustaceans (Kern \& Bell, 1984; Sun \& Fleeger, 1991) and other evertebrates (cf. Brey, 1989; Reise, 1987; de Alava \& Defoe, 1991; Titmus \& Badcock, 1981) are patchily distributed. The distributions of most polychaetes are also characterized by aggregations 
(e.g. Angel \& Angel, 1967; Brey, 1989; Reise, 1979). In contrast, species exhibiting territorial behaviour are usually uniformly distributed (Anderson \& Kendziorek, 1982; Gage \& Coghill, 1977; Reise, 1979; Roe, 1975). Levin (1981) showed that two spionid polychaetes (Pseudopolydora paucibranchiata, Streblospio benedicti) also fit into this scheme, being uniformly and randomly distributed.

The purpose of our studies was to describe the horizontal distribution pattern of Marenzelleria viridis (Verrill, 1873), a spionid from North American coastal waters that appeared in the North and Baltic seas during the 1980s. It has spread rapidly since it first invaded the inland coastal waters of the Baltic sea and is now the dominant species among the macrozoobenthos in many parts of the Baltic (Norkko et al., 1993; Persson, 1994; Zettler et al., 1995). It is hoped that the results presented here will provide a basis for future macrozoobenthos studies and for the selection of sampling methods that are more suitable for our investigation area.

\section{METHODS}

The investigation area (Fig. 1), the series of lagoons (each is a "Bodden" [German]) south of the Darss-Zingst Peninsula, is northeast of Rostock, has a length of about $40 \mathrm{~km}$ from west to east and occupies an area of $196.7 \mathrm{~km}^{2}$ (Correns, 1976). Its salinity is relatively low $(5 \%)$ and is subject to seasonal and interannual fluctuations owing to freshwater inflows and its connection to the Baltic sea (Zettler et al., 1995). Although the

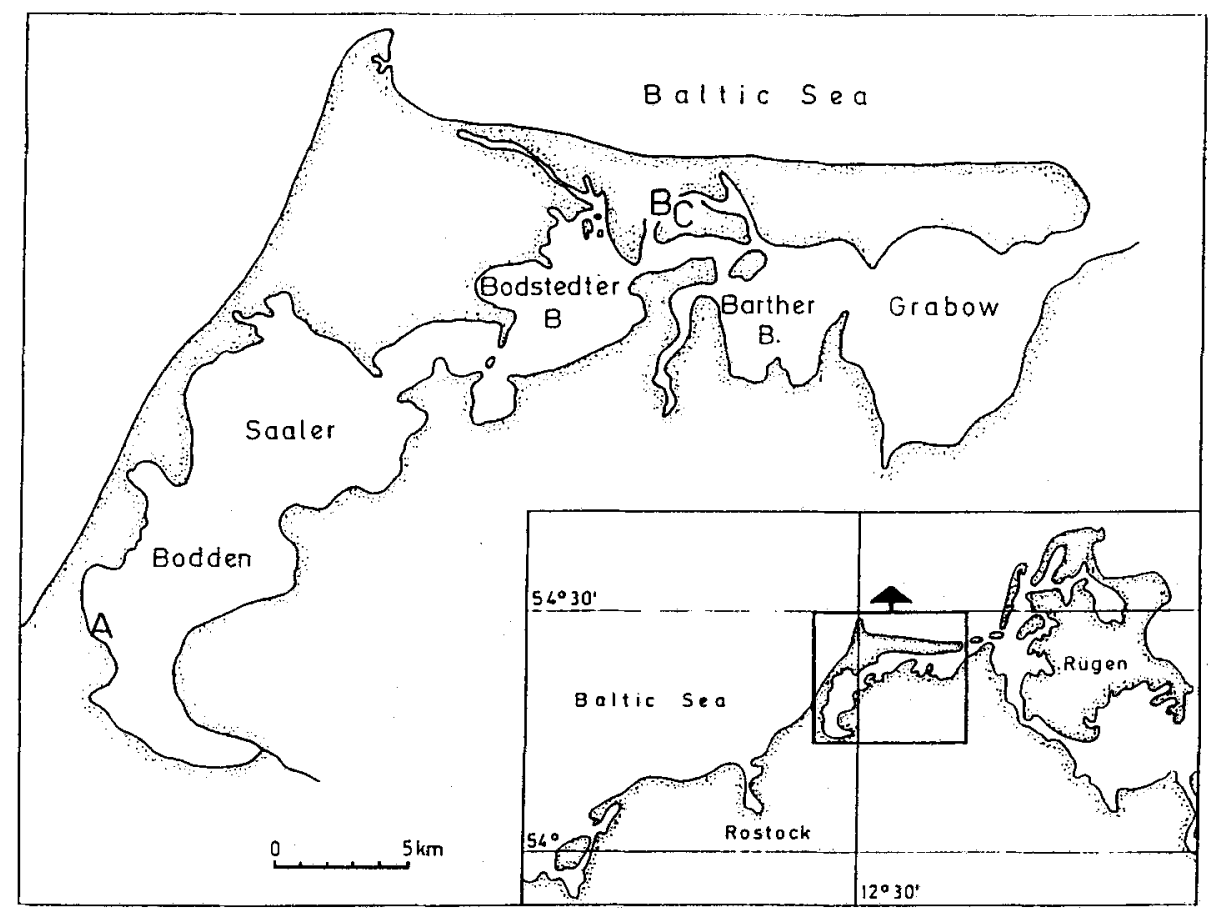

Fig. 1. Investigation area: the series of lagoons (Bodden) south of Darss-Zingst 
Table 1. Abiotic parameters and abundances during the present study

\begin{tabular}{|cccccc|}
\hline $\begin{array}{c}\text { Salinity } \\
(\%)\end{array}$ & $\begin{array}{c}\text { Org. content } \\
(\%)\end{array}$ & $\begin{array}{c}\text { Mean grain } \\
\text { size }(\mathrm{mm})\end{array}$ & $\begin{array}{c}\text { Degree of } \\
\text { sorting }\end{array}$ & $\begin{array}{c}\varnothing \text { ind./m } \\
M . \text { viridis }\end{array}$ & $\begin{array}{c}\varnothing \text { ind. } / \mathrm{m}^{2} \\
\text { chironomids }\end{array}$ \\
\hline $5.0 \pm 0.45$ & $1.23 \pm 0.69$ & $0.28 \pm 0.05$ & $1.45 \pm 0.21$ & $8492 \pm 973$ & $1699 \pm 74$ \\
\hline
\end{tabular}

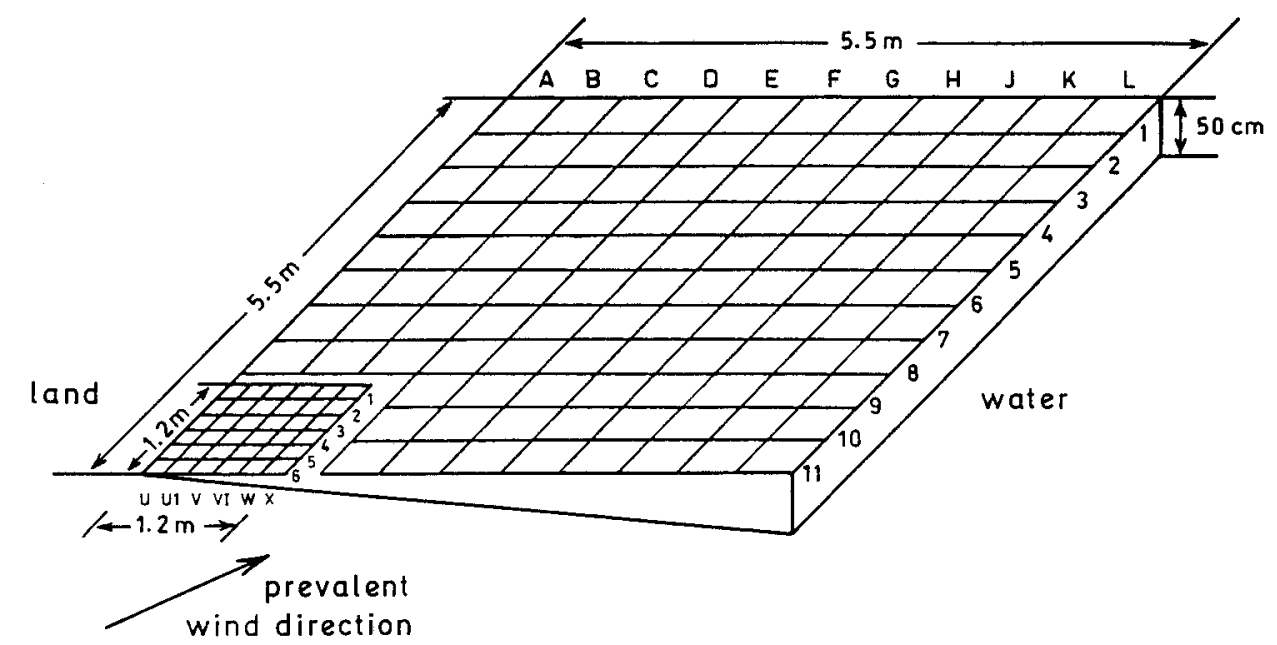

Fig. 2. Grids for the dispersion studies (large grid $=30.25 \mathrm{~m}^{2}$, small grid $=1.44 \mathrm{~m}^{2}$, head $=0.5 \mathrm{~m}$ )

mean depth at Station A was $0.6 \mathrm{~m}$, the sediment was also exposed occasionally at this station. The biotic and abiotic parameters are given in Table 1.

To measure the dispersion, an area of $30.25 \mathrm{~m}^{2}$ at Station A was divided into 121 subunits with an area of $0.25 \mathrm{~m}^{2}$ each (Fig. 2). Samples were collected by corer $\left(78.5 \mathrm{~cm}^{2} \times 35 \mathrm{~cm}\right.$ deep) from the centre of each subunit. To permit the investigation of smaller areas, an area measuring $1.44 \mathrm{~m}^{2}$ was split into 36 subunits of $0.04 \mathrm{~m}^{2}$ each, from which samples were taken with a smaller corer $\left(21.65 \mathrm{~cm}^{2} \times 35 \mathrm{~cm}\right)$. All samples were sieved ( $0.5 \mathrm{~mm}$ mesh) and fixed in borax-buffered formalin.

Morisita's (1959)* method was used to analyse the two-dimensional distribution pattern, and the abundances found in the samples were used for the calculations. The indices were calculated for the original area and for the progressive addition (cumulation) of the subunits to form squares $\left(\mathrm{n}^{2}\right.$ for $\mathrm{n}=1$ to 5 ). The cumulation of the separate areas began with A1 (Fig. 2). Lloyd (1967) and Iwao (1972) have published different methods

\footnotetext{
- Morisita (1959):

$$
I_{(0)}=n \cdot\left[\Sigma X_{i} \cdot\left(X_{i}-1\right)\right] /[N \cdot(N-1)]
$$
}

$\mathrm{n}=$ number of subunits; $\mathrm{N}=$ number of individuals in the whole area; $\mathrm{X}_{\mathbf{i}}=$ number of individuals in the subunits

$I_{(\delta)}<1$ uniform distribution; $I_{(\delta)}=1$ random distribution; $I_{(\delta)}>1$ patchy distribution

$F_{(n-1)}=\left(I_{(\delta)} \cdot(N-1)+n-N\right) /(n-1)$

If the left term is smaller than the right term for $F_{(p ; 1) ; 2)}$ then $p<0.01$ or 0.05 
Table 2. Dispersion analyses after Morisita (1959), Lloyd (1967) and Iwao (1972); significances denoted by * for $p<0.05, \cdots$ for $p<0.01$ and $\cdots$ for $p<0.001$

\begin{tabular}{|c|c|c|c|c|c|c|c|c|}
\hline \multirow{2}{*}{$\frac{\text { Morisita (1959) }}{\text { Area }\left(\mathrm{m}^{2}\right)}$} & \multicolumn{3}{|c|}{ Small grid } & \multicolumn{5}{|c|}{ Large grid } \\
\hline & 0.04 & 0.16 & 0.36 & 0.25 & 1 & 2.25 & 4 & 6.25 \\
\hline Adult $M$. viridis & $1.863^{*}$ & $1.375^{*}$ & $1.198 * *$ & $2.613^{\cdots}$ & $1.524^{\cdots}$ & $1.378^{*}$ & $1.404^{\cdots}$ & $1.085^{* *}$ \\
\hline Juvenile $M$. viridis & 1.035 & $1.026^{\circ}$ & 1.001 & $1.103^{* *}$ & $1.042^{*}$ & $1.03^{*}$ & $1.036^{*}$ & $1.022^{*}$ \\
\hline Ad. and juv. $M$. viridis & $1.058^{*}$ & $1.023^{*}$ & 1 & $1.130^{*}$ & $1.061^{\cdots}$ & $1.047^{\cdots}$ & $1.056^{*}$ & $1.028^{*}$ \\
\hline Chironomids & 1.105 & 0.955 & 0.994 & $1.350^{*}$ & $1.087^{*}$ & $1.072^{* *}$ & $1.02 * *$ & $1.053^{* *}$ \\
\hline \multicolumn{9}{|l|}{ Lloyd (1967) } \\
\hline Adult $M$. viridis & $1.875^{* * *}$ & $1.416^{* \cdots}$ & $1.259^{* \cdots}$ & $2.626^{* *}$ & $1.537^{\cdots}$ & $1.423^{\cdots}$ & $1.537^{\cdots} \cdots$ & $1.113^{\cdots} \cdot$ \\
\hline Juvenile $M$. viridis & 1.035 & 1.029 & 1.002 & $1.103^{*} \cdot$ & $1.044^{*} \cdots$ & $1.034^{* *}$ & $1.048^{*} \cdots$ & $1.029 \cdots$ \\
\hline Ad. and juv. $M$. viridis & $1.059^{\circ *}$ & $1.025^{\circ}$ & 1 & $1.131 *$ & $1.064^{* *}$ & $1.053^{* *}$ & $1.075^{\cdots} \cdot$ & $1.022^{\cdots}$ \\
\hline Chironomids & 1.106 & 0.95 & 0.992 & $1.352^{\cdots}$ & $1.124^{\cdots} \cdot$ & $1.081^{*} \cdots$ & $1.026^{*}$ & $1.07^{\cdots} \cdots$ \\
\hline \multicolumn{9}{|l|}{ Iwao (1972) } \\
\hline Adult $M$. viridis & 1.875 & 1.263 & 1.134 & 2.626 & 1.082 & 1.33 & 1.739 & 0.601 \\
\hline Juvenile $M$. viridis & 1.035 & 1.026 & 0.981 & 1.103 & 1.024 & 1.026 & 1.065 & 0.997 \\
\hline Ad. and juv. $M$. viridis & 1.059 & 1.014 & 0.98 & 1.131 & 1.04 & 1.044 & 1.104 & 0.944 \\
\hline Chironomids & 1.106 & 0.898 & 1.026 & 1.352 & 1.046 & 1.04 & 0.949 & 1.119 \\
\hline
\end{tabular}

for calculating dispersion indices. Lloyd's (1967) "index of patchiness" is practically identical to the Morisita index and yields no additional information (Burla et al., 1974; Patil \& Stiteler, 1974; Pielou, 1969, 1977). The results are compared in Table 2.

In Morisita's (1959) method, the dispersion indices are plotted versus the corresponding areas. This curve shows the "patch sizes".

The authors also calculated Cliff \& Ord's $(1973,1981)$ spatial autocorrelation, a method validated and introduced by Jumars et al. (1977) for analysing spatial autocorrelations of abundances in the marine benthos. The spatial autocorrelation expresses the dependence of the magnitude of a variable (in our case the abundance in a field) on the size of the same variable in geographically adjoining locations (Sokal, 1979). The indices calculated for all possible combinations of fields (joins) for each distance $\mathrm{k}$ (number of fields) are a measure of the correlation between the abundances in all fields with the distance k (Brey, 1989; Jumars et al., 1977). Both Moran's and Geary's indices for these calculations (Cliff \& Ord, 1973, 1981; Jumars et al., 1977) were used. Moran's index I is influenced by each deviation from the mean and by the location of extremes, whereas Geary's $c$ is a measure of the equality of adjoining abundances as a function of the distance ( $\mathrm{k}$ ) between the fields (Sokal, 1979). By plotting the indices versus the distances between fields in a correlogram, the results can be interpreted to yield the distribution pattern and the patch sizes.

The value of I varies between -1 (perfect negative autocorrelation) and +1 (perfect positive autocorrelation). The transformation $\mathrm{c}=(-1 \cdot \mathrm{c})+1$ was applied to Geary's index to permit both parameters to be plotted side by side. Brey (1989) and Sokal (1979) used similar transformations. In our case, $c<0$ means a negative autocorrelation, $c=0$ means no autocorrelation, and $c>0$ means a positive autocorrelation. Since the distributions of both Moran's I and Geary's c are asymptotically normal, it is possible to use the normal standard distribution and to test for significant differences (Cliff \& Ord, 1973; Brey, pers. comm.) 
After calculating the autocorrelation, we also analysed the correlations between the rank numbers of subpopulations and different species using Spearman's rank correlation coefficient (Sokal \& Rohlf, 1981). Reise's (1979) "rotation method" was used to describe spatial interactions between subpopulations (adult and juvenile Marenzelleria viridis) and between $M$. viridis and chironomids, and to permit comparison with Spearman's rank correlation. This involves calculating first the "index of patchiness" (Lloyd, 1967) for the real distributions (C) of two subpopulations that are being compared (addition of the abundances in the fields concerned), whereby one pattern is rotated through $90^{\circ}, 180^{\circ}$ and $270^{\circ}$, and the index $\left(\mathrm{C}_{(\mathrm{r})}\right)$ is calculated again for each of these angles. The mean of the indices for the rotated distributions and the standard deviation are then calculated. If no correlation exists, the indices for the real and rotated distributions will not differ significantly. The correlation is positive for $\mathrm{C}>\mathrm{C}_{(\mathrm{r})}$ and negative for $\mathrm{C}<\mathrm{C}_{(\mathrm{r})}$.

\section{RESULTS}

\section{Dispersion analysis}

\section{Adult Marenzelleria viridis}

The abundances of adult $M$. viridis are shown in Figure 3 . The distribution of the polychaete was distinctly patchy $\left(\mathrm{I}_{(0)}>1, \mathrm{p}<0.01\right)$ in both the large and small grids. The same result for each cumulation of grid squares $\left(1 \mathrm{~m}^{2}, 2.25 \mathrm{~m}^{2}, 4 \mathrm{~m}^{2}, 6.25 \mathrm{~m}^{2}\right)$ was obtained (Table 2, Fig. 4).

Analysis of the spatial autocorrelation yielded no significant values for the small grid (Table 3, Fig. 5). However, significant positive autocorrelations were found at the field

\begin{tabular}{|c|c|c|c|c|c|c|c|c|c|c|c|}
\hline & 0 & 22 & 21 & 3 & 0 & 0 & 0 & 28 & 146 & 21 & 9 \\
\hline & 4 & 7 & 9 & 2 & 0 & $\gamma$ & 6 & 0 & 13 & 6 & 2 \\
\hline & 0 & 1 & 0 & 0 & 1 & 122 & 11 & 0 & 1 & 0 & 18 \\
\hline & 1 & 1 & 4 & 3 & 21 & 21 & 26 & 1 & 1 & 0 & 15 \\
\hline & 26 & 4 & 0 & 2 & 4 & 2 & 1 & 14 & 2 & 9 & 0 \\
\hline & 4 & 13 & 1 & 15 & 6 & 1 & 0 & 14 & 11 & 1 & 0 \\
\hline & 10 & 2 & 1 & 15 & 14 & 0 & 2 & 3 & 7 & 2 & 6 \\
\hline & 1 & 0 & 2 & 9 & 2 & 1 & 0 & 1 & 3 & 24 & 12 \\
\hline & 2 & 0 & 0 & 1 & 0 & 10 & 2 & 4 & 5 & 3 & 7 \\
\hline & 0 & 0 & 2 & 0 & 2 & 4 & 0 & 5 & 16 & 3 & 5 \\
\hline & 0 & 2 & 0 & 0 & 1 & 1 & 2 & 0 & 11 & 13 & 1 \\
\hline
\end{tabular}
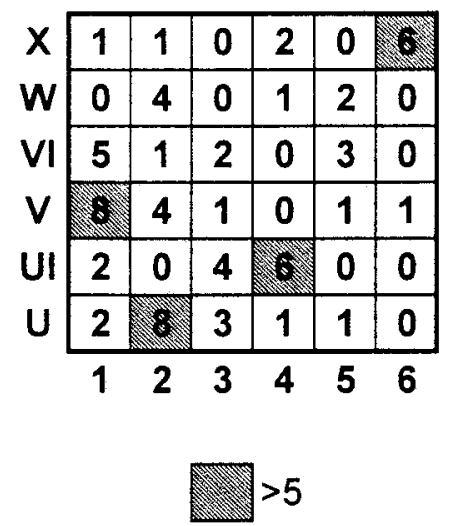

Fig. 3. Distribution of adult $M$. viridis 


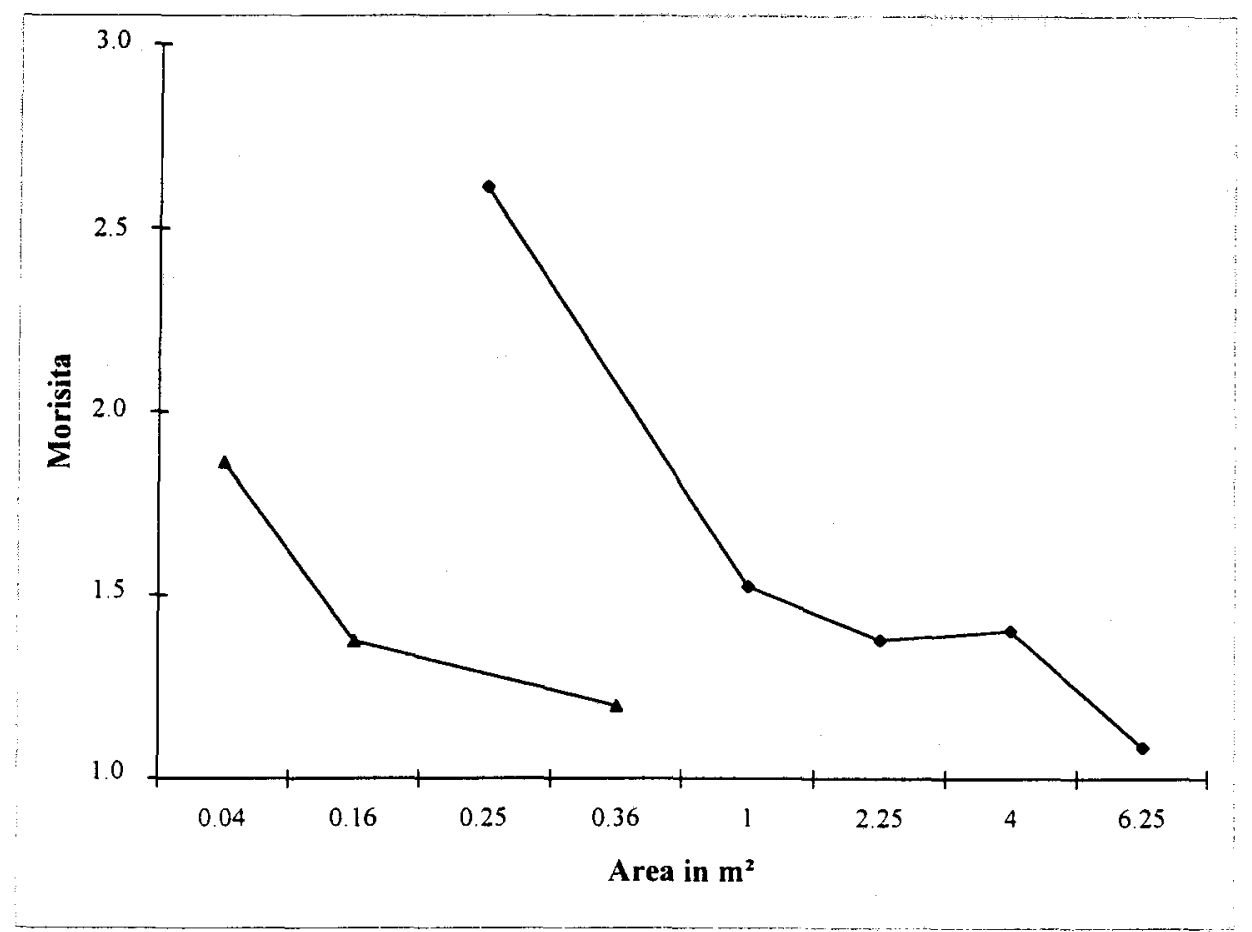

Fig. 4. Morisita's (1959) indices for adult $M$. viridis ( $\Delta=$ small grid, $\diamond=$ large grid); solid characters significant at the $\mathrm{p}<0.05$ level. See Table 2 for further information on significances

distances $k=1$ and $k=3$ in the large grid (Table 4, Fig. 5). A significant negative correlation was found at the greatest possible distance $(\mathrm{k}=10)$.

\section{Juvenile $M$. viridis}

Patchiness was also evident in the horizontal distribution of juvenile $M$. viridis (Table 2, Figs 6, 7). Dispersion analysis by Morisita's (1959) method for the large grid indicated a significantly patchy distribution up to the fourth level of cumulation $\left(6.25 \mathrm{~m}^{2}\right)$. In the small grid, the distribution of $M$. viridis juveniles was significantly patchy $(\mathrm{p}<0.05)$ only for areas of $0.16 \mathrm{~m}^{2}$.

Analysis using Cliff \& Ord's (1973) method yields no significance in the small grid (Table 3, Fig. 8). In the large grid, significant positive autocorrelations for field distances up to $\mathrm{k}=3$ and exclusively negative autocorrelations for greater distances between fields (Table 4, Fig. 8) were found.

\section{Total population of $M$. viridis}

Addition of the juvenile and adult $M$. viridis abundances resulted in a significantly patchy distribution in the large grid (Table 2, Figs 9, 10). A similar picture was obtained by adding the different subunits. In the small grid, significant patchiness of the $M$. viridis distribution was found only for areas of 0.04 and $0.16 \mathrm{~m}^{2}$. The distribution for an area of $0.36 \mathrm{~m}^{2}$ was random. 


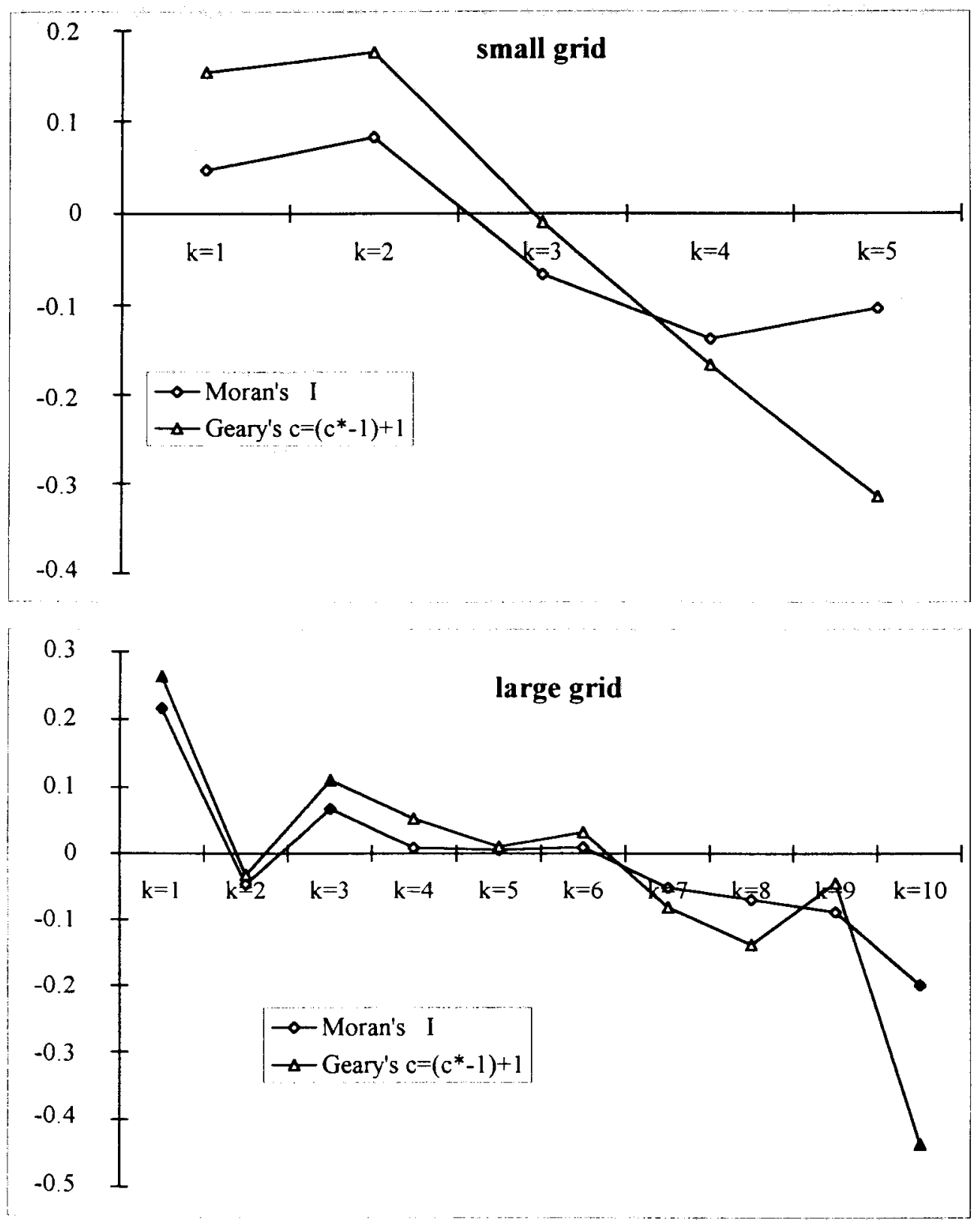

Fig. 5. Cliff \& Ord's (1973) spatial autocorrelation for adult $M$. viridis; solid characters significant at the $\mathrm{p}<0.05$ level. See Tables 3 and 4 for further information on significances 

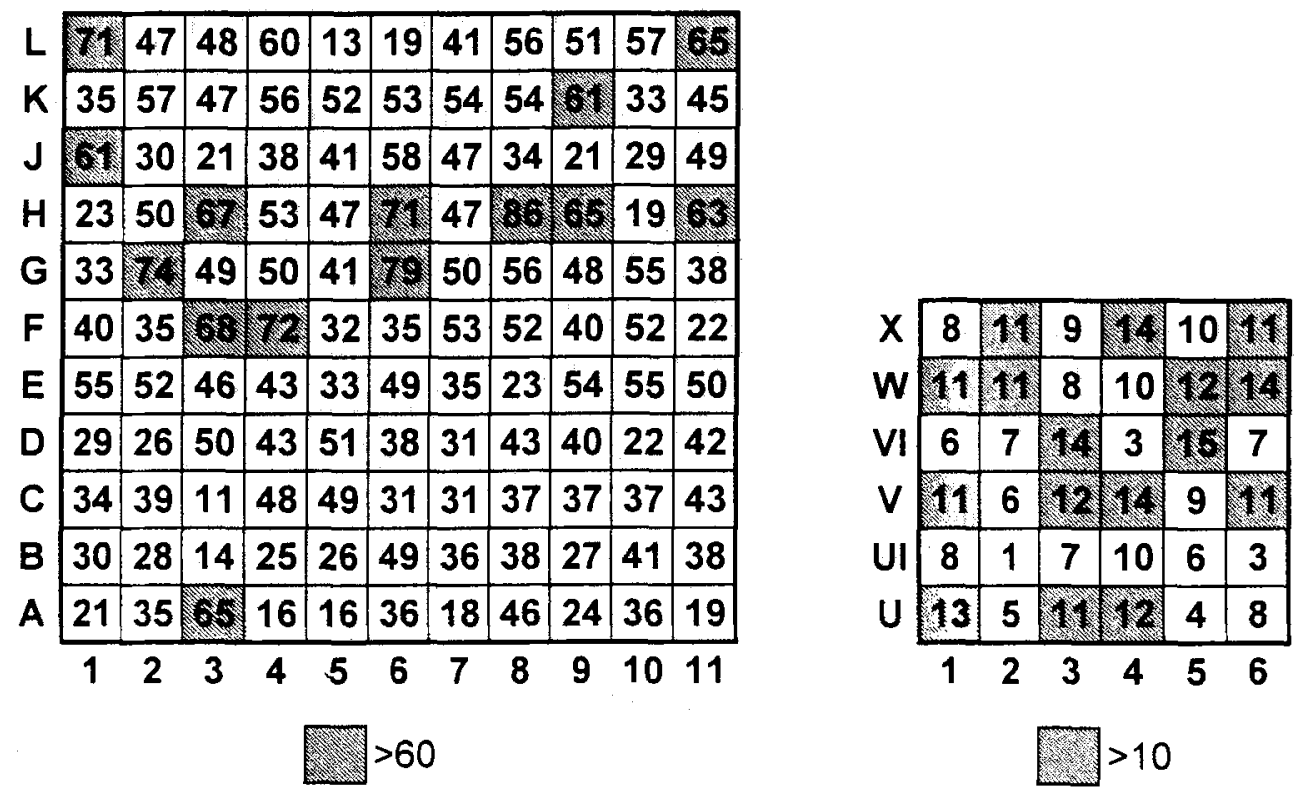

Fig. 6. Distribution of juvenile $M$. viridis

The spatial autocorrelation situation was similar to that for $M$. viridis juveniles. No significant autocorrelation was found in the small grid (Table 3, Fig. 11). Significant positive autocorrelations existed up to a distance between fields of $\mathrm{k}=3$. Negative autocorrelations were found for the joins at distances of $k=6$ to 10 between fields (Table 4, Fig. 11).

\section{Chironomids}

The chironomids belonged to the Chironomus plumosus and Ch. halophilus complexes. Significant patchiness was revealed at all cumulation levels $\left(0.25\right.$ to $\left.6.25 \mathrm{~m}^{2}\right)$ in the large grid by Morisita's (1959) method (Table 2, Figs 12, 13). In the small grid the distribution was not patchy but uniform or random.

The spatial autocorrelation was also analysed for the chironomids. Significant positive and negative values were found only for field distances of $k=2$ and $k=6$ respectively in the large grid (Table 4, Fig. 14).

\section{Rank and abundance correlation}

\section{Spearman's rank correlation}

Calculation of Spearman's rank correlation revealed a significant relationship $(p<0.01)$ between the distributions of adult and juvenile $M$. viridis (Table 5). In addition, a significant positive correlation $(\mathrm{p}<0.001)$ between the whole $M$. viridis population and the chironomids was found. Although no rank correlation was found between adult $M$. viridis and chironomids, the correlation between juvenile $M$. viridis and chironomids was positive at the $\mathrm{p}<0.001$ level. 


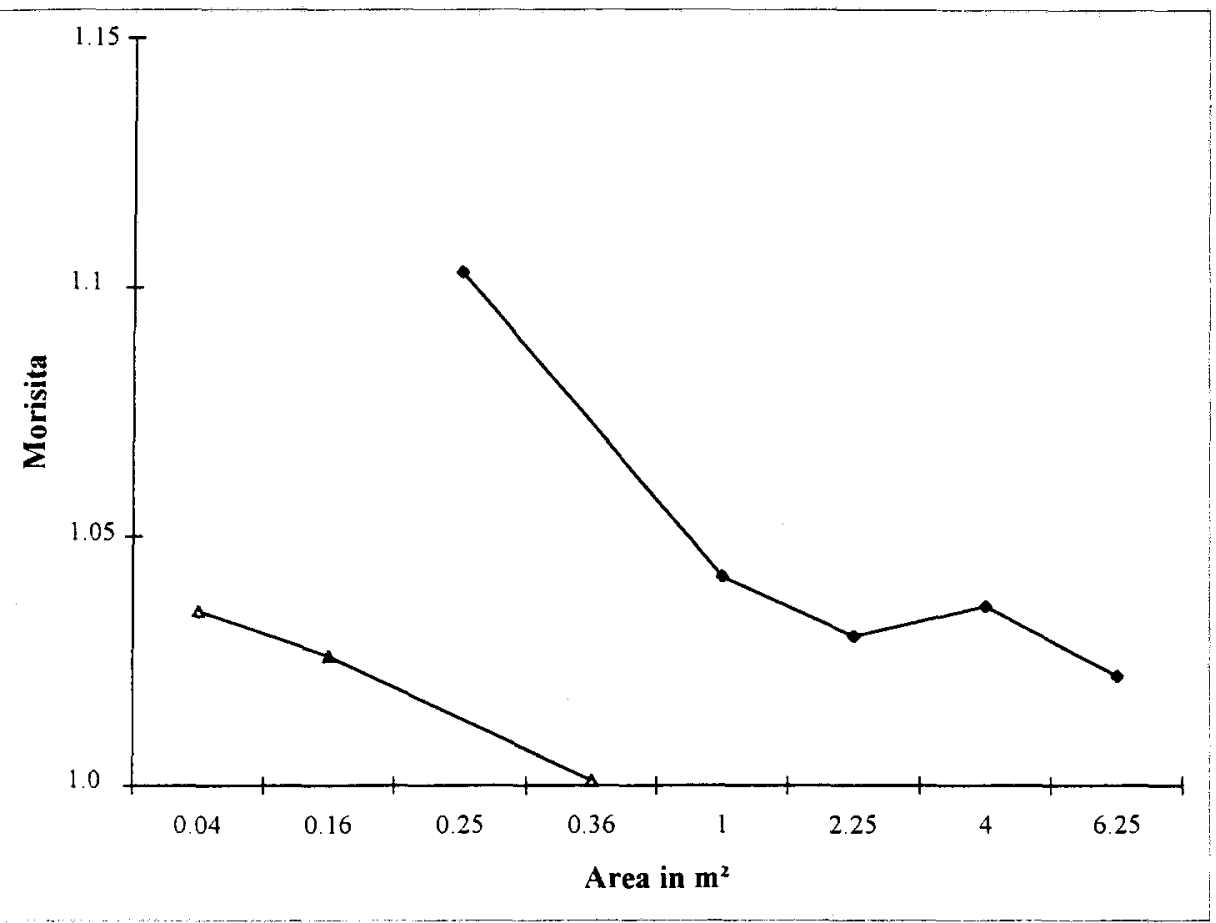

Fig. 7. Morisita's (1959) indices for juvenile $M$. viridis ( $\Delta=$ small grid, $\diamond=$ large grid); solid characters significant at the $p<0.05$ level. See Table 2 for further information on significances

Table 3. Cliff \& Ord's (1973) spatial autocorrelation for the small grid (1.44 $\left.\mathrm{m}^{2}\right)$; no significances were measured

\begin{tabular}{|c|c|c|c|c|c|}
\hline $\begin{array}{l}\text { Distance } \\
\text { Joins }\end{array}$ & $\begin{array}{c}k=1 \\
220\end{array}$ & $\begin{array}{c}k=2 \\
320\end{array}$ & $\begin{array}{c}\mathrm{k}=3 \\
324\end{array}$ & $\begin{array}{c}k=4 \\
256\end{array}$ & $\begin{array}{c}k=5 \\
140\end{array}$ \\
\hline \multicolumn{6}{|l|}{ Juvenile $M$. viridis } \\
\hline Moran's I & -0.008 & -0.012 & -0.012 & -0.09 & -0.034 \\
\hline Geary's $c=\left(c^{*}-1\right)+1$ & -0.109 & -0.033 & -0.006 & -0.04 & 0.239 \\
\hline \multicolumn{6}{|l|}{ Adult $M$. viridis } \\
\hline Moran's I & 0.047 & 0.082 & -0.066 & -0.137 & -0.104 \\
\hline Geary's c $=\left(c^{*}-1\right)+1$ & 0.154 & 0.176 & -0.009 & -0.167 & -0.315 \\
\hline \multicolumn{6}{|l|}{ Ad. and juv. $M$. viridis } \\
\hline Moran's I & -0.1 & 0.02 & -0.004 & -0.038 & -0.056 \\
\hline Geary's $c=\left(c^{*}-1\right)+1$ & -0.154 & 0.031 & 0.016 & -0.031 & 0.125 \\
\hline \multicolumn{6}{|l|}{ Chironomids } \\
\hline Moran's I & -0.034 & -0.095 & 0.024 & 0.013 & -0.041 \\
\hline Geary's $c=\left(c^{*}-1\right)+1$ & 0.033 & 0.019 & 0.076 & -0.089 & 0.009 \\
\hline
\end{tabular}




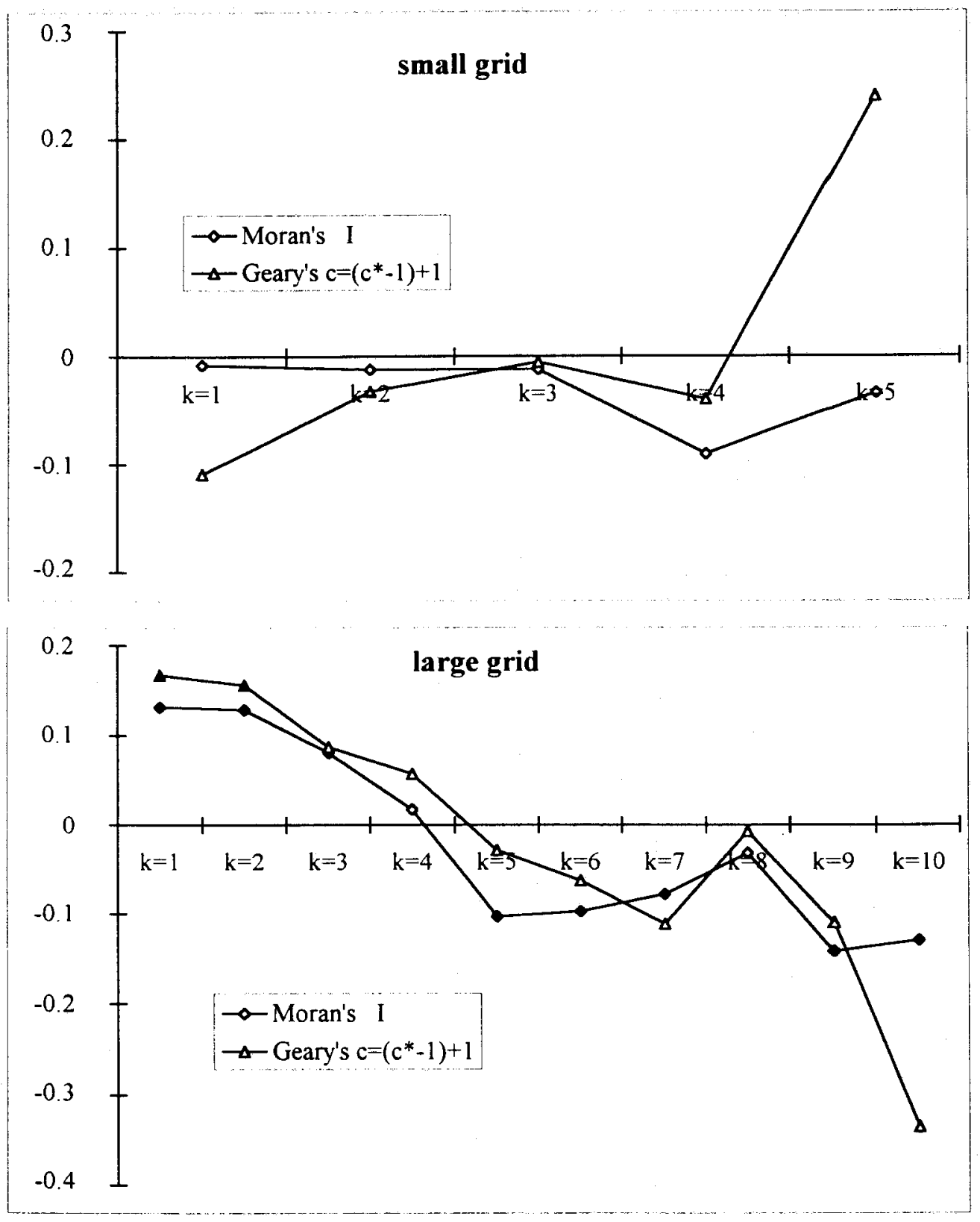

Fig. 8. Cliff \& Ord's (1973) spatial autocorrelation for juvenile $M$. viridis; solid characters significant at the $p<0.05$ level. For further information on significances, see Tables 3 and 4 


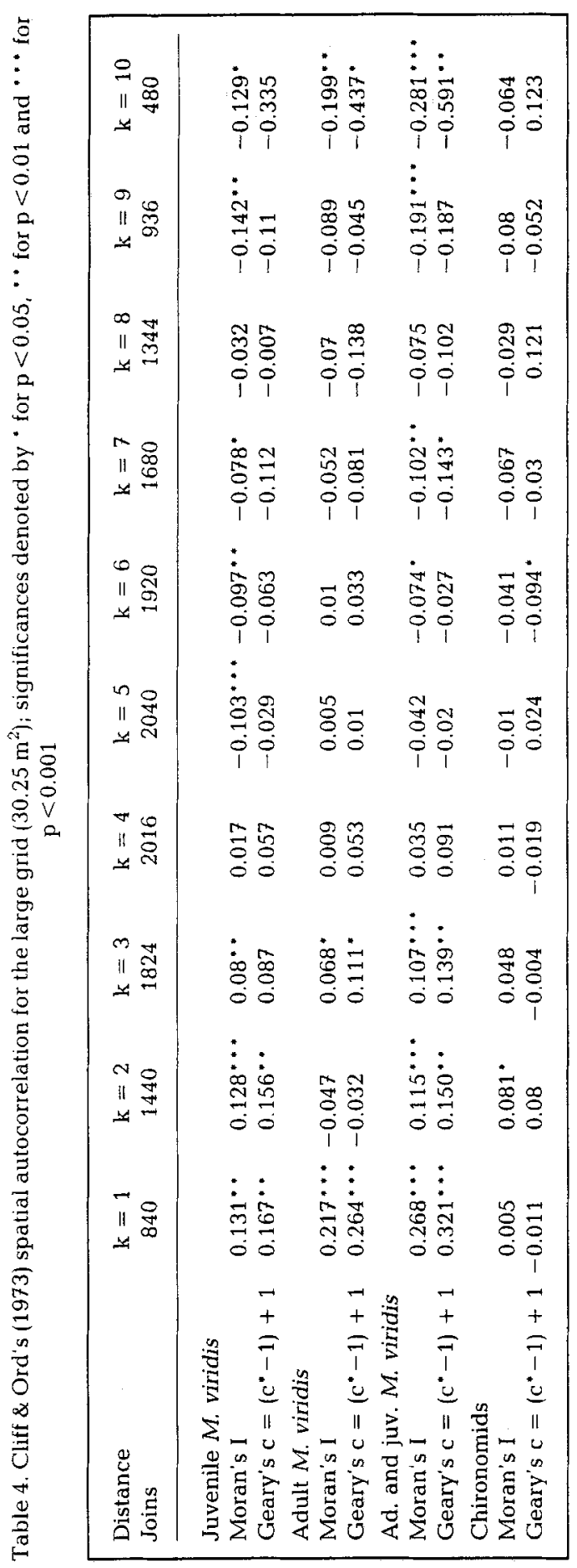



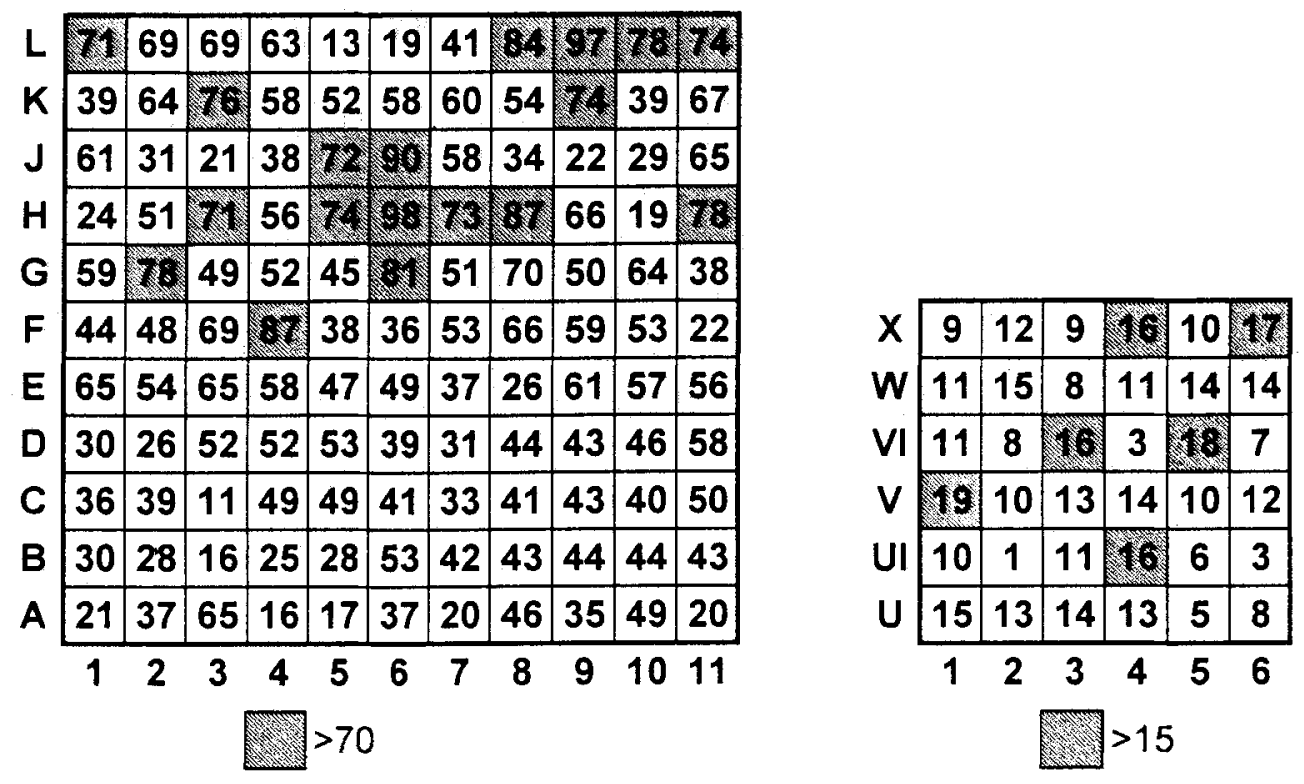

Fig. 9. Distribution of the whole $M$. viridis population

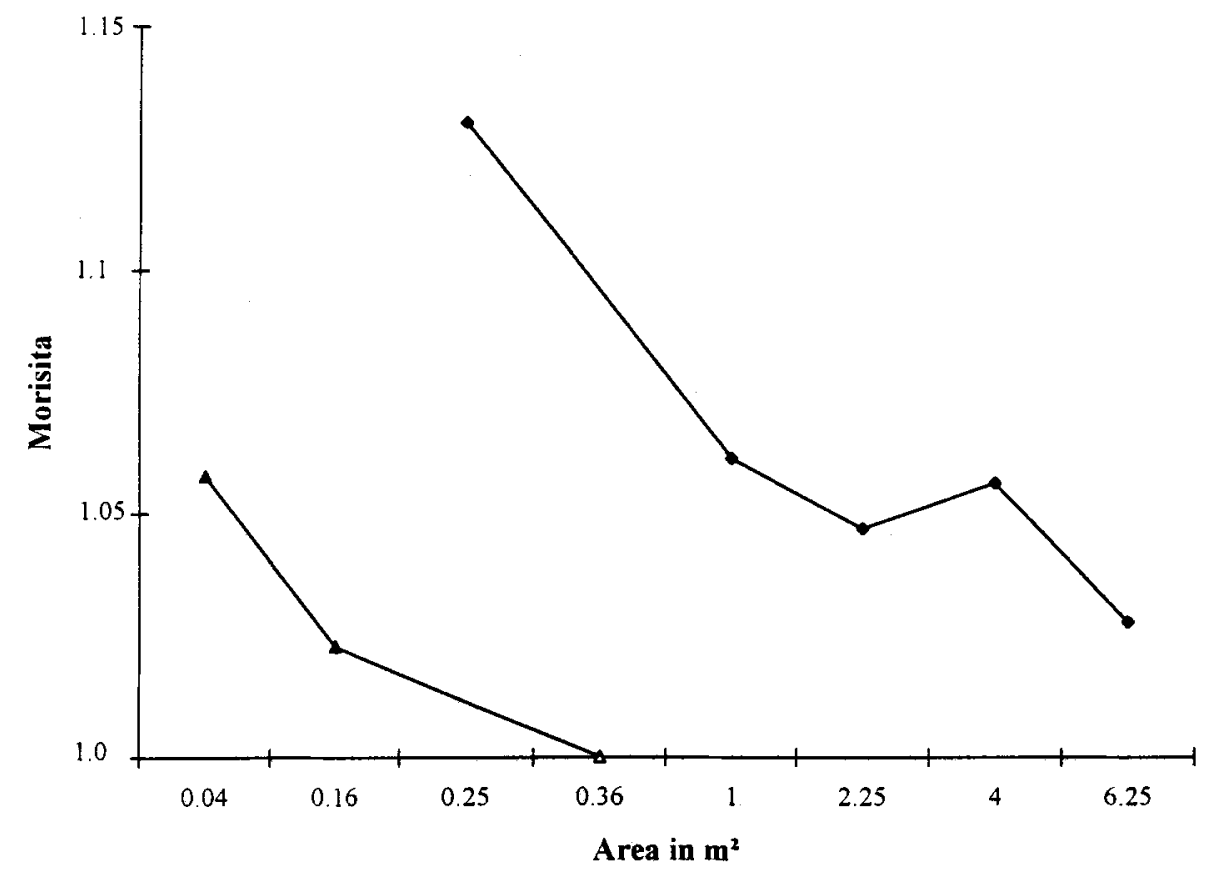

Fig. 10. Morisita's (1959) indices for the whole $M$. viridis population ( $\Delta=$ small grid, $\diamond=$ large grid); solid characters significant at the $\mathrm{p}<0.05$ level. For further information on significances, see Table 2 


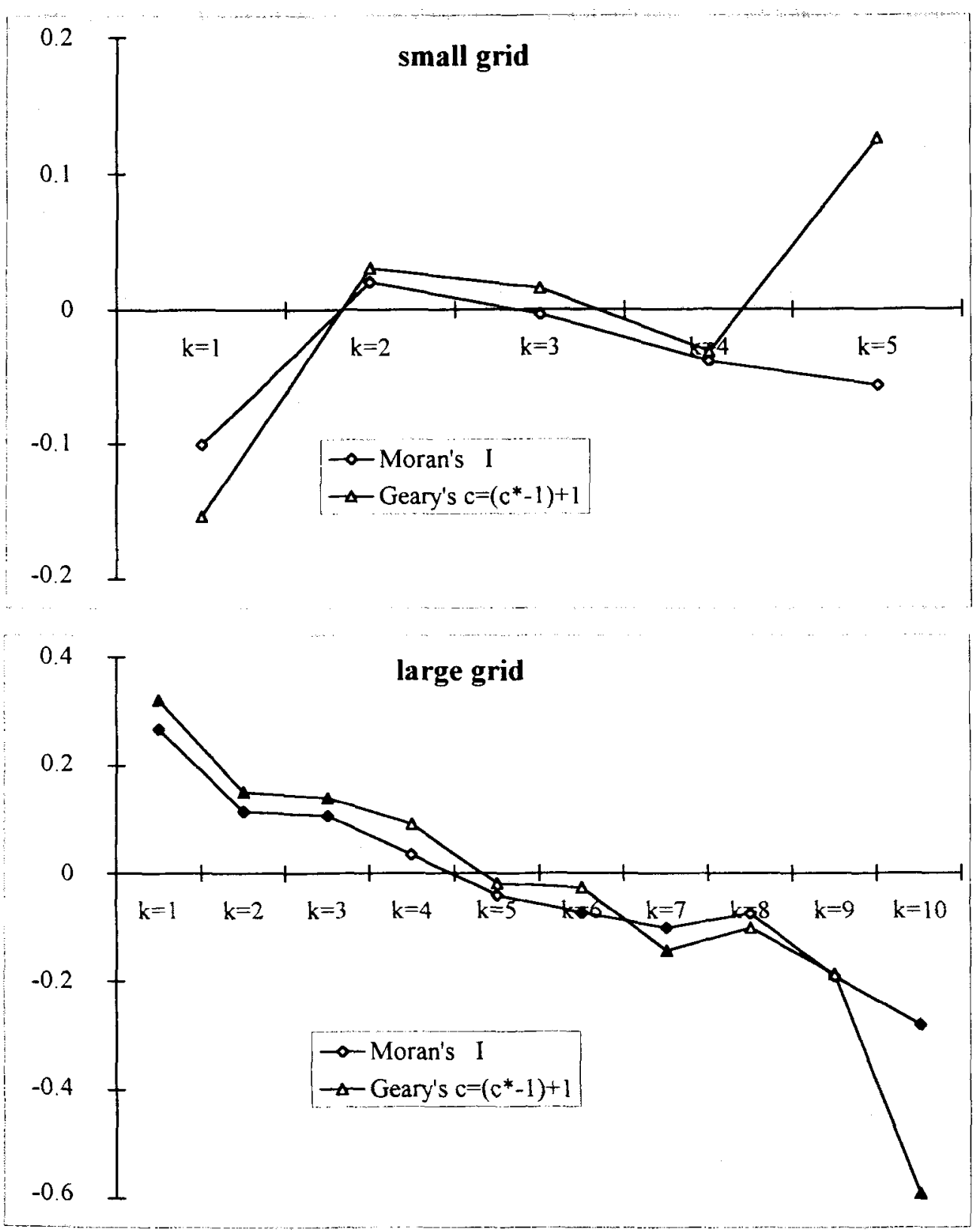

Fig. 11. Cliff \& Ord's (1973) spatial autocorrelation for the whole $M$. viridis population; solid characters significant at the $\mathrm{p}<0.05$ level. For further information on significances, see Tables 3 and 4 

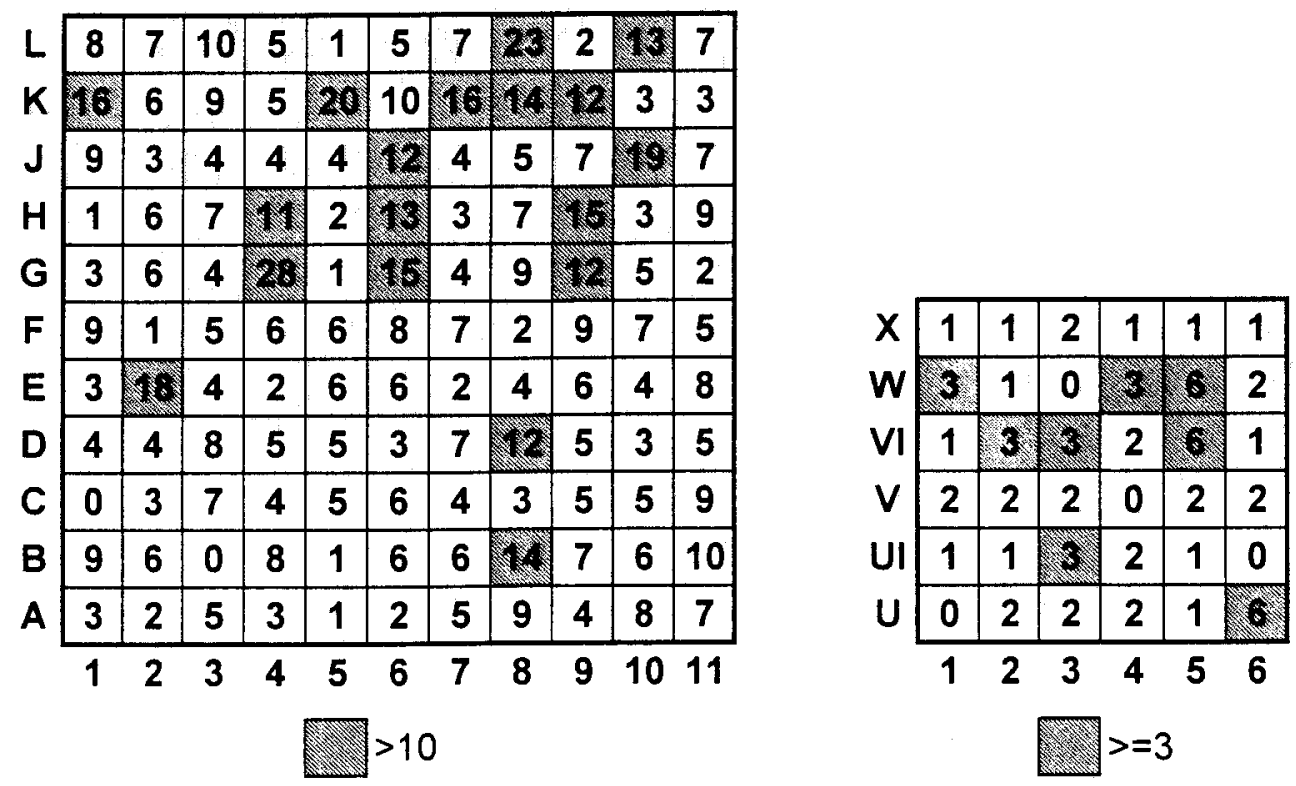

Fig. 12. Distribution of chironomids

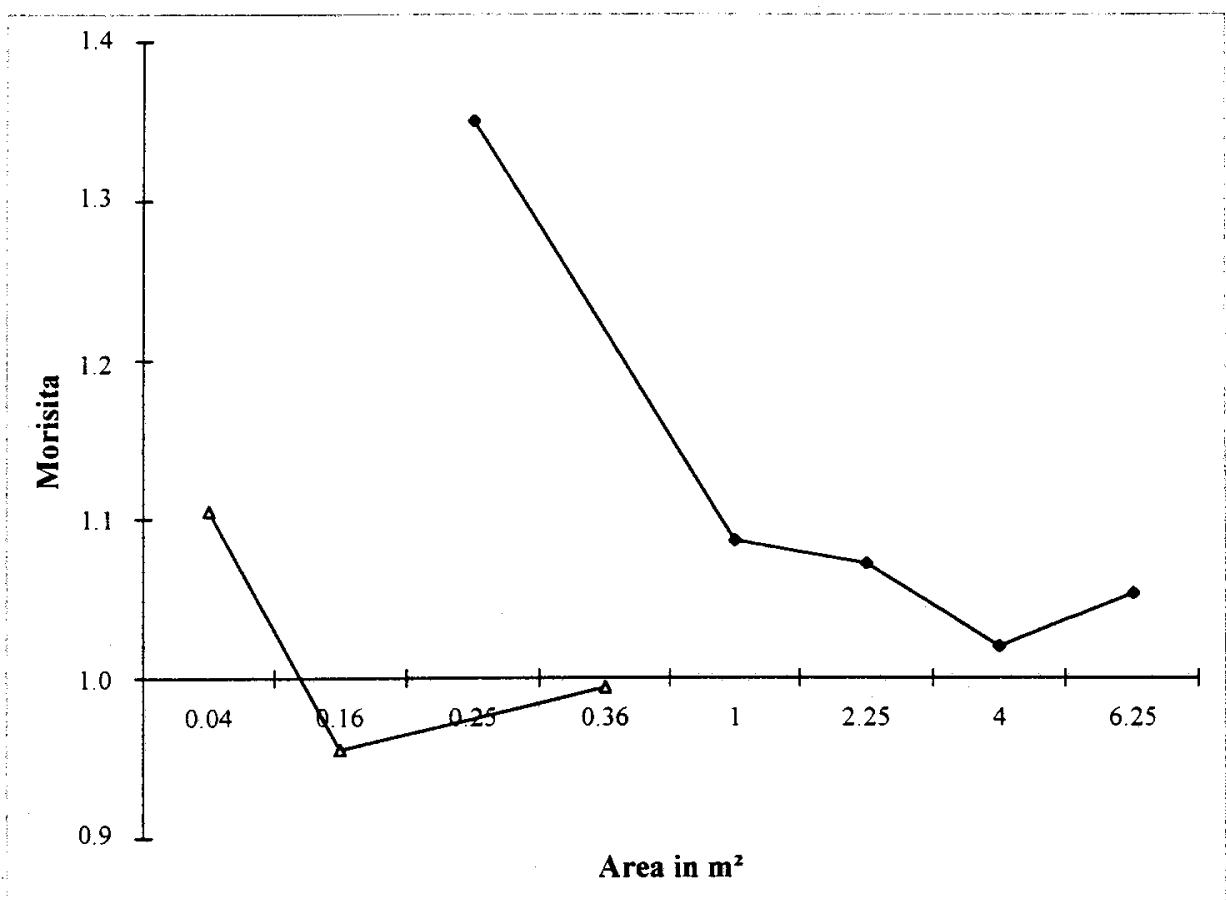

Fig. 13. Morisita's (1959) indices for chironomids $(\triangle=$ small grid, $\diamond=$ large grid); solid characters significant at the $p<0.05$ level. For further information on significances, see Table 2 


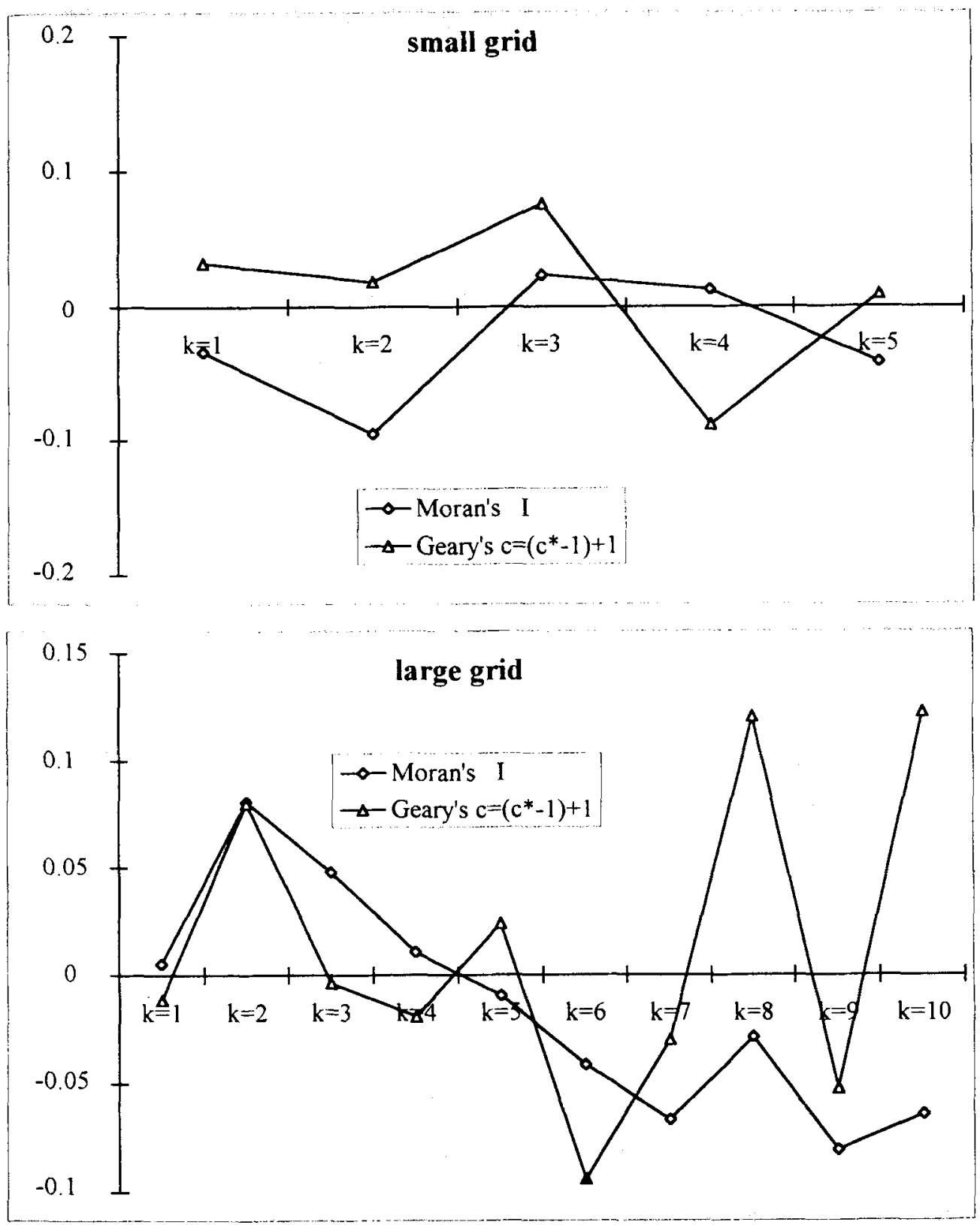

Fig. 14. Cliff \& Ord's (1973) spatial autocorrelation for chironomids; solid characters significant at the $p<0.05$ level. For further information on significances, see Tables 3 and 4 
Table 5. Analysis of the Spearman rank correlations

\begin{tabular}{|lcccc|}
\hline & $\mathrm{r}_{\mathrm{s}}$ & $\mathrm{z}$ & $\mathrm{u}(1-\alpha / 2)$ & $\mathrm{p}$ \\
\hline Adult and juvenile $M$. viridis & 0.272 & 2.977 & 2.58 & 0.01 \\
Whole $M$. viridis population - chironomids & 0.343 & 3.759 & 3.29 & 0.001 \\
Adult $M$. viridis - chironomids & 0.051 & 0.559 & 1.96 & n.s. \\
Juvenile $M$. viridis - chironomids & 0.424 & 4.642 & 3.29 & 0.001 \\
\hline
\end{tabular}

Rotation method (correlation between abundances)

The results achieved by this method are shown in Table 6 . In a comparison of the adult and juvenile $M$. viridis populations, the quotient $\mathrm{m} * / \mathrm{m}$ (the value $\mathrm{C}$ ) for the real distribution was significantly larger than the value $\mathrm{C}_{(\mathrm{r})}$ for the rotated distribution. The correlation between the two subpopulations was therefore positive.

This procedure revealed no correlation between adult $M$. viridis and chironomids, but, like the Spearman rank coefficient, it did prove a positive correlation between both juvenile $M$. viridis and the entire $M$. viridis population on the one hand and chironomids on the other.

Table 6 . Results of the rotation test: $\mathrm{C}=\mathrm{m} * / \mathrm{m}$ for the real distribution; $\mathrm{C}_{\mathrm{r} \mathrm{r}}=\mathrm{m} * / \mathrm{m}$ for the rotated distribution; $\mathrm{SD}=$ standard deviation

\begin{tabular}{|lccc|}
\hline & $\mathrm{C}$ & mean $\left(\mathrm{C}_{(\mathrm{r})}\right)$ & $\mathrm{SD}$ \\
\hline Adult and juvenile $M$. viridis & 1.131 & 1.107 & 0.012 \\
Whole $M$. viridis population - chironomids & 1.124 & 1.106 & 0.010 \\
Adult $M$. viridis - chironomids & 1.553 & 1.508 & 0.056 \\
Juvenile $M$. viridis - chironomids & 1.105 & 1.082 & 0.009 \\
\hline
\end{tabular}

\section{DISCUSSION}

Analysis of spatial distribution patterns and their stability and dynamics forms an important basis for our understanding of the ecology of plants and animals as well as their interactions with endogenic and exogenic factors (Patil \& Stiteler, 1974; Pielou, 1977; Clark \& Evans, 1954; Trueblood, 1991). Existing distribution patterns are the result of the interactions of organisms with their environment (Lloyd, 1967; Dankers \& Beukema, 1981), for instance through competition (Jumars, 1975; Levin, 1981, 1984), reproduction and colonization (Butman, 1987; Jumars \& Eckman, 1983) and predation (Reise, 1991).

The starting point for the present study was an investigation into the colonization of inland coastal waters of the South Baltic by Marenzelleria viridis (Zettler et al., 1995). Knowledge of the small-scale horizontal distribution of this spionid is needed for more far-reaching studies into its migratory behaviour and interaction with the indigenous macrofauna. In his first description of the species, Verrill (1873) drew attention to the uneven distribution of $M$. (Scolecolepides) viridis: "It is so gregarious that in certain spots hundreds may be found within a square foot, but yet a few yards away, on the same kind 
of ground, none whatever may be found." The considerable variation he observed in $M$. viridis abundances led us to suspect that it would be patchy, and our methods enabled us to show that "patchiness" is indeed characteristic of its distribution. Brey (1989) and Eckman (1979) noted that other spionids (Pygospio elegans, Pseudopolydora kempi) are also patchily distributed. Levin (1981) reported that the distributions of the spionids Pseudopolydora paucibranchiata and Streblospio benedicti are respectively uniform and random and concluded that this was a result of their territorial behaviour (inter- and intraspecific competition).

The spatial autocorrelation shows clearly that the distribution was independent of extreme values (Brey, 1989; Cliff \& Ord, 1973, 1981; Sokal, 1979). The patch size was heterogenous. The diameter of the first one found was about $1 \mathrm{~m}(\mathrm{k}=1)$, while the second was about $3 \mathrm{~m}(\mathrm{k}=3)$. Studying the dispersion of intertidal communities on soft bottoms, Eckman (1979) interpreted Chatfield's autocorrelation for species such as Manayunkia aestuarina and Pygospio elegans as meaning that smaller patches are due to exogenous factors (sediment bars).

The smallest patches of juvenile $M$. viridis found had an area of 0.25 to $0.36 \mathrm{~m}^{2}$. No patch of maximum size according to Morisita's (1959) method was found.

Juvenile $M$. viridis exhibited a significant spatial autocorrelation (Moran's I) up to a field distance of $\mathrm{k}=3$. However, Geary's $\mathrm{c}$ was no longer significant at this field distance. Therefore, we may conclude that the patch size was between 4 and $9 \mathrm{~m}^{2}$. However, it is also conceivable that smaller patches merge to form larger aggregations.

The results of our analysis of the whole $M$. viridis population were similar to those for the juvenile subpopulation: the population was patchily distributed, but Morisita's method revealed no particular "patch size".

The spatial autocorrelation also yielded a picture similar to that shown by juvenile $M$. viridis. The patch size in this case was estimated to be about $9 \mathrm{~m}^{2}$. The chironomids were also found to be patchily distributed with no specific maximum patch size. The minimum patch size can be assumed to be about $0.25 \mathrm{~m}^{2}$. Titmus \& Badcock (1981) found no patchiness among Chironomus spp., but reported that the distributions of the chironomid genera Polypedilum, Procladius and Tanypus resembled those we found. In our analysis of the spatial autocorrelation, significant relationships only for $\mathrm{k}=2$ and $\mathrm{k}=6$ were found. The area of the patches was around $4 \mathrm{~m}^{2}$, but comparison with other methods suggests in this case, too, that smaller patches merge to cover larger areas.

The variability in the spatial distribution of $M$. viridis is probably due to sediment structure (relief). The species was most commonly found on slight elevations $(5$ to $10 \mathrm{~cm}$ ) in the substrate and rarely, if at all, in "valleys". There are three possible explanations for this.

(1) The "hills" are a result of bioturbation and burrowing by $M$. viridis itself. These spionids line their burrows with slime and even erect a low wall around the entrance (Zettler et al., 1994). For a density of $8000 \mathrm{ind} . / \mathrm{m}^{2}$, a mean burrow diameter of $2 \mathrm{~mm}$ and a penetration depth of $30 \mathrm{~cm}$, the amount of sediment excavated would be $7.51 / \mathrm{m}^{2}$. Even if it is less, burrowing activity can be expected to have some impact on sediment structure.

(2) The activity of the animals could contribute to the compaction and thus the "trapping" of sediment. This would make the patch less prone to erosion and encourage the accumulation of sediment. Other burrowing polychaetes are known to increase sediment strength (Fager, 1964; Sanders et al., 1962; Rhoads et al., 1978; Yingst \& 
Rhoads, 1978). Brey (1989), however, pointed out that Eckman et al. (1981) postulated a destabilizing effect of burrowing animals on the sediment as a result of purely physical considerations. For large burrow diameters ( $>1 \mathrm{~mm})$ on the other hand, reduced erosion can be observed due to a reduction in turbulent flow (protruding burrow mouths). In contrast, Eckman et al. (1981), Brey (1989), and other authors believe that bacteria, diatoms and filamentous algae producing slime that glues sediment particles together might play a more significant role in this respect. The nutrients produced by burrowing macrofauna, from the sediment (irrigation), may promote the growth of microfauna and microflora (Aller, 1980). Brey (1989) suspects that the burrows themselves may act as scaffolding or form slime-stabilized sediment. "Hills" created in this way could therefore be centres of attraction for benthic suspension and substrate-feeders.

(3) Abiotic factors such as wave action can give rise to the formation of a substrate relief, the "hills" of which attract both polychaetes and chironomids. The "burial" of depressions due to sediment transport and redeposition would likewise affect colonization patterns (Maurer \& Aprill, 1979). Naturally, interactions between these factors are also possible.

Various studies have shown that benthic species show preferences for specific sediment types (e.g. Kinner et al., 1974; Meadows \& Campbell, 1972). Sediment preferences, besides salinity and competition, also influence the distribution of $M$. viridis (Zettler et al., 1995). Like Verrill (1873), Essink \& Kleef (1993) and Atkins et al. (1987), we have observed that adult specimens show an affinity for sandy substrates. In comparative studies, for instance, we counted mean abundances of around $2000 \mathrm{ind} . / \mathrm{m}^{2}$ at Station C (mean grain size $=0.29 \mathrm{~mm}$, organic content $=1 \%$, water content $=28 \%$ ) compared with only about 200 ind $/ \mathrm{m}^{2}$ on the average in the muddy sediment at Station B (mean grain size $=0.23 \mathrm{~mm}$, organic content $=2 \%$, water content $=35 \%$ ) only $10 \mathrm{~m}$ away. The highest abundances in our investigation area were found on sandy substrates (Zettler, 1993; Zettler et al., 1995).

The positive rank and abundance correlations found in this present investigation indicate that attraction centres exist. The previously mentioned affinity of $M$. viridis for sandy substrates is definitely the decisive factor because the sediment surface in the "valleys" is muddy owing to the accumulation of detritus, and oxygen consumption may also be higher there. Apart from the inhibitory effect of colonization by burrowing animals on settlement by juveniles of other benthic species, Gallagher et al. (1983) also drew attention to a positive effect. Studying patchy distributions of Hobsonia florida and Tanais spp., they found positive correlations with various organisms. Burrowing animals seemed to encourage the re-colonization of defaunated substrates. Sarda et al. (1995, and pers. comm.) referred to $M$. viridis as a cold-tolerant opportunist which precedes and encourages colonization of substrates by other benthic evertebrates after defaunation by ice action. Encouragement of this kind can actually be expected in view of the positive correlation between the distributions of $M$. viridis and chironomids. However, significant correlations with chironomids were found only for juvenile $M$. viridis. This would be explained by the previously mentioned production of nutrients, by the burrower $M$. viridis, from the sediment which promote the growth of microorganisms serving as food for chironomids (Aller, 1980; Johnson, 1987). Kajak (1987) reported that faeces encourage chironomid growth, and faeces from $M$. viridis could be a good substrate for microorganisms. 
Further, the positive patch correlations indicate principal suspension feeding, while surface deposit feeders have negative correlations between age groups or are territorial. According to Dankers \& Beukema (1981), the principal factors governing the distribution of benthic organisms in estuarine systems are water motion, temperature, tide, sediment type, salinity and biotic factors. Correspondingly, the factors that might possibly explain the positive rank and abundance correlations between $M$. viridis and chironomids, and the patchiness of the former could include:

(1) centres of attraction (e.g. "hills") created by abiotic or biotic activity;

(2) similar or identical food requirements (organic matter, particle size) for these suspension and detritus feeders (Dauer et al., 1981; Polzin, 1988; Johnson, 1987; Reise, 1979; Sanders et al., 1962);

(3) predation by fish (Reise, 1991; Woodin, 1982);

(4) mortality among senile $M$. viridis;

(5) the possible emigration of adult $M$. viridis due to poor living conditions (food, oxygen, mud accumulation, competition) or for reproduction.

Essink \& Kleef (1993) reported that adult and juvenile worms prefer different sediments, and our observations confirm this report. The highest abundances of juveniles, having between 15 to 40 segments, were reached on muddy substrates (Zettler et al., 1995), and Reise (1991) observed that juvenile Arenicola marina settled mainly in socalled "nurseries" away from the adult populations and did not move on to areas populated by adult animals until they had reached a certain size. Unfortunately, the juvenile $M$. viridis specimens used in our dispersion studies had a mean segment number of 70 and already exhibited an affinity for sand.

It is not known whether adult $M$. viridis influence the settlement of planktic larvae. However, Dauer et al. (1981) reported that respiratory currents caused by $M$. viridis draw the larvae of other spionids (Streblospio benedicti) into their burrows and thus negatively affect settlement. Tamaki (1985) also reported that the spionid Pseudopolydora paucibranchiata negatively influences the settlement of larval Armandia spp. and that ophelid larvae settle preferentially in areas where the spionid population density is relatively low. Levin (1982) has observed interspecific aggression between the spionids $M$. viridis, Polydora ligni and Spio setosa. Other spionids (Polydora ligni, P. ciliata) are known to ingest planktic larvae (Breese \& Phibbs, 1972; Daro \& Polk, 1973). In view of these reports, it seems quite possible that adult $M$. viridis have a negative intraspecific effect on settlement by larvae and juvenile benthic forms; a report which we were unable to verify.

Since only three taxa occur in our investigation area, we were unable to study the distribution of $M$. viridis in areas with a more diversified fauna. However, the effects of macrozoobenthos representatives exhibiting territorial and predacious behaviour (Hediste diversicolor) on the distribution of the spionids will be the subject of future investigations.

Acknowledgements. We wish to thank Dr. M. Hubert for her valuable help with the statistical analysis. We also express our gratitude to Prof. $K$. Reise for helpful comments after reading the manuscript. This contribution arose in connection with work funded by the Federal Ministry of Research and Technology under Grant No. 03F 0031A. 


\section{LITERATURE CITED}

Alava, A. de \& Defoe, O., 1991. Distributional pattern and population dynamics of Excirolana armata (Isopoda: Cirolanidae) in a Uruguayan sandy beach. - Estuar. coast. Shelf Sci. 33, 433-444.

Aller, R. C., 1980. Relationships of tube-dwelling benthos with sediment and overlying water chemistry. In: Marine benthic dynamics. Ed. by K. R. Tenore \& B. C. Coull. Univ. of South Carolina Press, Columbia, South Carolina, 285-308.

Anderson, D. J. \& Kendziorek, M., 1982. Spacing patterns in terebellid polychaetes. - J. exp. mar. Biol. Ecol. 58, 193-205.

Angel, H. H. \& Angel, M. V., 1967. Distribution pattern analysis in a marine benthic community. Helgoländer wiss. Meeresunters. 15, 445-454.

Atkins, S. M., Jones, A. M. \& Garwood, P. R., 1987. The ecology and reproductive cycle of a population of Marenzelleria viridis (Annelida: Polychaeta: Spionidae) in the Tay Estuary. - Proc. R. Soc. Edinb. 92B, 311-322.

Breese, W. P. \& Phibbs, F. D., 1972. Ingestion of bivalve molluscan larvae by the polychaete annelid Polydora ligni. - Veliger 14, 274.

Brey, T., 1989. Der Einfluß physikalischer und biologischer Faktoren auf Struktur und Dynamik der sublitoralen Macoma-Gemeinschaft der Kieler Bucht. - Ber. Inst. Meeresk. Kiel 186, 1-248.

Burla, H., Schenker, H.-J. \& Stahel, W., 1974. Das Dispersionsmuster von Teichmuscheln (Anodonta) im Zürichsee. - Oecologia 17, 131- 140 .

Butman, C. A., 1987. Larval settlement of soft-sediment invertebrates: The spatial scales of pattern explained by active habitat selection and the emerging role of hydrodynamical processes. Oceanogr. mar. Biol. 25, 113-165.

Clark, P. J. \& Evans, F. C., 1954. Distance to nearest neighbor as a measure for spatial relationships in populations. - Ecology 35, 445-453.

Cliff, A. D. \& Ord, J. K., 1973. Spatial autocorrelation. Pion, London, 180pp.

Cliff, A. D. \& Ord, J. K., 1981. Spatial processes. Pion, London, 266pp.

Correns, M., 1976. Charakteristische morphometrische Daten der Boddenkette südlich des Darß und des Zingst. - Vermessungstechnik 24, 459-461.

Dankers, N. \& Beukema, J. J., 1981. Distributional patterns of macrobenthic species in relation to some environmental factors, - Rep. Wadden Sea Working Group 4, 69-103.

Daro, M. H. \& Polk, P., 1973. The autecology of Polydora ciliata along the Belgian coast. - Neth. J. Sea Res. 6, 130-140.

Dauer, D. M., Maybury, C. A. \& Ewing, R. M., 1981. Feeding behaviour and general ecology of several spionid polychaetes from the Chesapeake Bay. - J. exp. mar. Biol. Ecol. 54, 21-38.

Eckman, J. E., 1979. Small-scale patterns and processes in a soft-substratum, intertidal community.J. mar. Res. 37, 437-457.

Eckman, J. E., Nowell, A. R. M. \& Jumars, P. A., 1981. Sediment destabilization by animal tubes. - J. mar. Res. 39, 361-374.

Essink, K. \& Kleef, H. L., 1993. Distribution and life cycle of the North American spionid polychaete Marenzelleria viridis (Verrill, 1873) in the Ems Estuary. - Neth. J. aquat. Ecol, 27, $237-246$.

Fager, E. W., 1964. Marine sediments: Effects of a tube-building polychaete. - Science, N. Y. 143, 356-359.

Gage, J. D. \& Coghill, G. G., 1977. Studies on the dispersion patterns of Scottish sea loch benthos from contiguous core transects. In: Ecology of marine benthos. Ed. by B. C. Coull. Univ. of South Carolina Press, Columbia, South Carolina, 319-337.

Gallagher, E. D., Jumars, P. \& Trueblood, D. D., 1983. Facilitation of soft-bottom benthic succession by tube builders. - Ecology $64,1200-1216$.

Iwao, S., 1972. Application of the $\mathrm{m}^{*}-\mathrm{m}$ method to the analysis of spatial patterns by changing the quadrat size. - Res. Populat. Ecol. 14, 97-128.

Johnson, R. K., 1987. Seasonal variation in diet of Chironomus plumosus (L.) and C. anthracinus Zett. (Diptera: Chironomidae) in mesotrophic Lake Erken. - Freshwat. Biol. 17, 525-532.

Jumars, P. A., 1975. Methods for measurement of community structure in deep-sea macrobenthos. Mar. Biol. 30, 245-252.

Jumars, P. A., Thistle, D. \& Jones, M. L., 1977. Detecting two dimensional spatial structure in biological data. - Oecologia 28, 109-123. 
Jumars, P. A. \& Eckman, J. E., 1983. Spatial structure within deep-sea benthic communities. In: The sea. Ed. by G. T. Rowe. Wiley, New York, 8, 399-451.

Kajak, Z., 1987. Determinants of maximum biomass of benthic Chironomidae (Diptera), - Entomol. scand. (Suppl.) 29, 303-308.

Kern, J. C. \& Bell, S. S., 1984. Spatial heterogeneity in size-structure of meiofaunal-sized invertebrates on small-spatial scales (meters) and its implications. - J. exp. mar. Biol. Ecol. 78, 221-235.

Kinner, P., Maurer, D. \& Leathem, W., 1974. Benthic invertebrates in Delaware Bay: animalsediment association of the dominant species. - Int. Revue ges. Hydrobiol. 59, 685-701.

Levin, L. A., 1981. Dispersion, feeding behaviour and competition in two spionid polychaetes. - J. mar. Res. 39, 99-117.

Levin, L. A., 1982. Interference interactions among tube-dwelling polychaetes in a dense infaunal assemblage. - J. exp. mar. Biol. Ecol. 65, 107-119.

Levin, L. A, 1984. Life history and dispersal patterns in a dense infaunal polychaete assemblage: Community structure and response to disturbance. - Ecology 65, 1185-1200.

Lloyd, M., 1967. Mean crowding. - J. Anim. Ecol. 36, 1-30.

Maurer, D. \& Aprill, G., 1979. Intertidal benthic invertebrates and sediment stability at the mouth of Delaware Bay. - Int. Revue ges. Hydrobiol. 64, 379-403.

McGurk, M. D., 1987. Natural mortality and spatial patchiness: reply to Gulland. - Mar. Ecol. Prog. Ser. 39, 201-206.

Meadows, P. S. \& Campbell, J. I., 1972. Habitat selection by aquatic invertebrates. - Adv. mar. Biol. 10, 271-382.

Morisita, M., 1959. Measuring of the dispersion of individuals and analysis of the distributional patterns. - Mem. Fac. Sci. Kyushu Univ. (Ser. E: Biol. ) 2, 215-235.

Norkko, A., Bonsdorff, E. \& Boström, C., 1993. Observations of the polychaete Marenzelleria viridis (Verrill) on a shallow sandy bottom on the south coast of Finland. - Mem. Soc. Fauna Flora fenn. $69,112-113$.

Patil, G. P. \& Stiteler, W. M., 1974. Concepts of aggregation and their quantification: A critical review with some new results and applications. - Res. Populat. Ecol. 15, 238-254.

Perrson, L.-E., 1994. Nya arter ändrar Ostersjön mer än vara föroreningar. - Fauna Flora 5, 33-37.

Pielou, E. C., 1969. An introduction to mathematical ecology. Wiley-Interscience, New York, 286pp

Pielou, E. C., 1977. Mathematical ecology. Wiley, New York, 385pp.

Polzin, W.-P., 1988. Experimentell-ökologische Untersuchungen an Chironomiden-Larven unter Berücksichtigung der Nahrungsaufnahme und -verwertung. Dipl.-Arb. Univ. Rostock, 55pp.

Poole, R. W., 1974. An introduction to quantitative ecology. McGraw-Hill, New York, 532pp.

Reise, K., 1979. Spatial configurations generated by motile benthic polychaetes. - Helgoländer wiss. Meeresunters. 32, 55-72.

Reise, K., 1987. Spatial niches and long-term performance in meiobenthic Plathelminthes of an intertidal lugworm flat. - Mar. Ecol. Prog. Ser. 38, 1-11.

Reise, K., 1991. Mosaic cycle in the marine benthos. In: The mosaic-cycle concept of ecosystems. Ed. by H. Remmert. Springer, Berlin, 61-82.

Rhoads, D. C., Yingst, J. Y. \& Ullman, W. J., 1978. Seafloor stability in central Long Island Sound: Part I. Temporal changes in erodibility of fine-grained sediment. In: Estuarine interactions. Ed. by M. L. Wiley. Acad. Press, New York, 221-244.

Roe, P., 1975. Aspects of the life history and of territorial behavior in young individuals of Platynereis bicaniculata and Nereis vexillosa (Annelida, Polychaeta). - Pacif. Sci. 29, 341-348.

Sanders, H. L., Goudsmit, E. M., Mills, E. L. \& Hampson, G. E., 1962. A study of the intertidal fauna of Barnstable Harbor, Massachusetts. - Limnol. Oceanogr. 7, 63-79.

Sarda, R., Forman, K. \& Valiela, I., 1995. Macrofauna of a southern New England salt marsh: seasonal dynamics and production. - Mar. Biol. 121, 431-445.

Sastre, M. P., 1985. Aggregated patterns of dispersion in Donax denticulatus. - Bull. mar. Sci. 36, $220-224$.

Sokal, R. R., 1979. Ecological parameters inferred from spatial correlograms. In: Contemporary quantitative ecology and related parameters. Ed. by G. P. Patil \& M. Rosenzweig. Int. Co-op. Publ. House, Fairland, 695pp.

Sokal, R. R. \& Rohlf, F. J., 1981. Biometry. Freeman, San Francisco, 859pp. 
Sun, B. \& Fleeger, J. W., 1991. Spatial and temporal patterns of dispersion in meiobenthic copepods. - Mar. Ecol. Prog. Ser. 71, 1-11.

Tamaki, A., 1985. Inhibition of larval recruitment of Armandia sp. (Polychaeta: Opheliidae) by established adults of Pseudopolydora paucibranchiata (Okuda) (Polychaeta: Spionidae) on an intertidal sand flat. - J. exp. mar. Biol. Ecol. 87, 67-82.

Titmus, G. \& Badcock, R. M., 1981. Distribution and feeding of larval Chironomidae in a gravel pit lake. - Freshwat. Biol. 11, 263-271.

Trueblood, D. D., 1991. Spatial and temporal effects of terebellid polychaete tubes on soft-bottom community structure in Phosphorescent Bay, Puerto Rico. - J. exp. mar. Biol. Ecol. 149, 139-159.

Verrill, A. E., 1873. Report upon the invertebrate animals of Vineyard Sound and the adjacent waters, with an account of the physical characters of the region. - U.S. Rep. Commnr Fish. 1873 (P. 1), 295-778.

Woodin, S. A., 1982. Browsing: important in marine sedimentary environments? Spionid polychaete examples. - J. exp. mar. Biol. Ecol. 60, 35-45.

Yingst, J. Y. \& Rhoads, D. C., 1978. Seafloor stability in central Long Island Sound: Part II. Biological interactions and their potential importance for seafloor erodibility. In: Estuarine interactions. Ed. by M. L. Wiley, Acad. Press, New York, 245-260.

Zettler, M. L., 1993. Untersuchungen zur Biologie und Ökologie von Marenzelleria viridis (Polychaeta: Spionidae) in der Darß-Zingster-Boddenkette. Dipl.-Arb. Univ. Rostock, 80pp.

Zettler, M. L., Bochert, R. \& Bick, A., 1994. Röhrenbau und Vertikalverteilung von Marenzelleria viridis (Polychaeta: Spionidae) in einem inneren Küstengewässer der südlichen Ostsee. Rostocker meeresbiol. Beitr. 2, 215-225.

Zettler, M. L., Bick, A. \& Bochert, R., 1995. Distribution and population dynamics of Marenzelleria viridis (Polychaeta: Spionidae) in a coastal water of the southern Baltic. - Arch. Fish. mar. Res. 42, 209-224. 